\title{
Biennial (2007/8) Crisis of Sarotherodon galilaeus Fishery in Lake Kinneret (Israel): A Synopsis
}

\author{
Moshe Gophen*
}

MIGAL-Scientific Research Institute, POB 831, Kiryat Shmone, 11016, Israel

*Corresponding author: Dr. Moshe Gophen, MIGAL-Scientific Research Institute, POB 831, Kiryat Shmone, 11016, Israel; E-mail: Gophen@Migal.org.il

Received: April 27, 2021; Accepted: May 03, 2021; Published: May 10, 2021

\section{Background}

There are 19 native fish species in Lake Kinneret [1,2] of which 6 are endemic, 2 are extinct, 5 are intentional and non-intentional introductions, and 10 under commercial exploitation and of the commercial species, Sarotherodon galilaeus (Arabic: Musht Abiad; Hebrew: Amnoon HaGalil; Common: Galilee St. Peter Fish) [1-6] and the stocked mugilids $[2,3,7]$ have the highest market value. The silver carp (introduced), bleaks (native), the common carp (nonintentionally invasion), Barbus spp, and 3 other tilapia species have lower market values (Tables 1 and 2) [8].

Sarotherodon galilaeus (SG) is a common native fish species in Lake Kinneret. The fish is a nest-builder and bi-parental mouth-breeder with tropical-Ethiopian origin. The adult stages are planktivorous filter-feeders specified on utilization of the phyrrhophyte Peridinium gatunenze $[7,9]$. The juveniles and fingerlings with a total length (TL)

Table 1: Scientific names and features (endemism, commercial fishery) of the Kinneret native fish species (Ben-Tuvia 1978; Gophen 1992;2018; 2019).

\begin{tabular}{|l|c|}
\hline Scientific Name & Features \\
\hline Mirogrex terrae sanctae & Commercial, endemic \\
\hline Acanthobrama lissneri & Commercial, endemic \\
\hline Carasobarbus canis & Commercial \\
\hline Luciobarbus longiceps & Commercial \\
\hline Capoeta damascina & Commercial \\
\hline Garra jordanica & \\
\hline Hemmigramocapoeta nana & Commercial \\
\hline Pseudophoxinus kervilei & Commercial \\
\hline Coptodon zillii & Commercial \\
\hline Oreochromis aureus & Commercial, endemic \\
\hline Sarotherodon galilaeus & Endemic, no recent recording \\
\hline Tristramella simonis simonis & Endemic \\
\hline Tristramella sacra & Commercial \\
\hline Haplochromis flaviijosephi & \\
\hline Clarias gariepinus & \\
\hline Aphanius mento & \\
\hline Oxynoemacheilus jordanicus & \\
\hline Salaria fluviatilis & \\
\hline
\end{tabular}

Table 2: Scientific names and features (commercial fishery, introduction, invasion) of the Kinneret non-native fish species (Ben-Tuvia 1978).

\begin{tabular}{|l|c|}
\hline Scientific Name & Features \\
\hline Mugil cephalus & Commercial, introduced \\
\hline Mugil capito & Commercial, introduced \\
\hline Hypophthalmichthys molitrix & Commercial, Introduced \\
\hline Cyprinus carpio & Commercial, invasion \\
\hline Anguilla Anguilla & Commercial, invasion \\
\hline Salmo gairdneri irideus & Commercial, invasion \\
\hline Gambusia affinis & Invasion \\
\hline
\end{tabular}

below $5 \mathrm{~cm}$ are visual particulate attack-feeders which selectively prey on zooplankton. Displays are carried out in the shallows (0.53 -m depth) and nests are constructed on sand-silt-clay bottom in the shallows uncovered by vegetation. The nests are flat depressions (20-40$\mathrm{cm}$ diameter) which are easily devastated by wave action immediately after spawning. The number of eggs in one clutch varies between 1000 and 3000, and fertilization takes place externally. Immediately after fertilization, collected by both parents' mouths. Each couple may repeat 3-4 reproductive cycles in one season. Reproductive activity is initiated not before daily temperature in the shallows is above $21^{\circ} \mathrm{C}$. Moreover, the reproductive process is very sensitive and the activity of swimmers or boat shading might cause an interruption. Newborn juveniles are sheltered 3-4 weeks inside the parents' mouths and later on in shoals between submerged vegetation. Due to its flavored taste, SG is in high market demand. In the North-Eastern region of Lake Kinneret, there are open shallow lagoons which are highly favored by SG during the spawning season due to their ecological suitability for reproductive activity. Local fishermen are aware of that and used to intensify fishing pressure there from spring to early summer seasons. Therefore, a legislation imposing a two-month fishing ban in that area every spawning was passed. Moreover, due to climate change, severe river discharge was documented, accompanied by water scarcity and lake water level decline, which led to the disappearance of the lagoons. Nevertheless, it was documented that SG successfully used spawning grounds in other parts of the lake shallows. As part of SG population maintenance, a long-term program of fingerling production for stocking $\left(2-5 \times 10^{6}\right.$ fingerlings, each of weight $5 \mathrm{~g}$, per year) was implemented. 
Table 3: Annual landings (ton/year) of total fishery, Sarotherodon galilaeus, bleaks, and barbels (and their percentage of the total) during two periods 1959-2002 and 2003-2016 (Sarid and Shapiro 1959-2017).

\begin{tabular}{|l|c|c|}
\hline & $\mathbf{1 9 5 9 - 2 0 0 2}$ & $\mathbf{2 0 0 3 - 2 0 1 6}$ \\
\hline Total Fishery & 1969 & 670 \\
\hline Bleaks & $970(57 \%)$ & $234(35 \%)$ \\
\hline S. galilaeus & $243(14 \%)$ & $144(21 \%)$ \\
\hline O. aureus & $129(8 \%)$ & $9(1 \%)$ \\
\hline Barbels & $98(6 \%)$ & $40(6 \%)$ through 2010 \\
\hline
\end{tabular}

\section{Landings (1959-2017).}

A summary of landings (ton/year) of total fishery, SG, barbels (BAL), bleaks, and Oreochromis aureus (OA) is given in Table 3.

Two principle parameters strongly influence total catch: fishing effort and the crisis of SG population. Moreover, fishing effort is the result of marketing potential. Marketing of bleaks was abolished in the late 1990s. Because barbel fishery is not affected by marketing and probably was not damaged by ecological factors, it is suggested that its landing decline is due to decrease in fishing effort. The market capabilities of SG are unlimited, therefore, its fishery decline is mostly related to ecological conditions. The fishery decline of $O$. aureus is probably indicative of the elimination of its stocking.

In the period 1987-2015, routine bi-monthly night acoustic surveys were carried out along 14 trans-sections directed perpendicularly to the shoreline towards the open water area, in order to document fish targets within a depth range of between $2 \mathrm{~m}$ from surface to bottom. Annual averages are presented in Figure 1, which shows a prominent elevation of population size since the 2000s. Because the majority of the recorded target signals are due to bleaks, the increase in their population during the period 2000-2016 was prominent. Results given in Figure 2 indicate a quasi-cycled population size of Sarotherodon galilaeus in Lake Kinneret [6,10]: a 10-12 periodical years of landing onset and offset cycling. Nevertheless, the exceptional decline in the early 2000s was followed by a consequent increase in landing of Sarotherodon galilaeus, which is clearly shown in Figure 2. Moreover, a clear indication of the positive relations between bleak and SG landings is presented in Figure 3. The more the bleak biomass removed by fishery, the higher the catch of S. galilaeus. Consequently, fish population size [11] has an inverse relation with the landing (Figure 4) of the most common fish, namely bleaks. Intensification of bleak landing is accompanied by a decrease in their population size.

Simultaneous implementation of natural and anthropogenic parameters created optimal ecological combination for the initiation of the $S$. galilaeus crisis. This crisis was demonstrated by the following: 1: stocking reduction [9]; 2: fish size (TL) reduction caused by the use of illegal fishing nets with smaller mesh sizes (unpublished data); 3: dominant replacement of Peridinium by Cyanobacteria [4]; 4: significant reduction in bleak fishing due to market depletion: 5: outbreak of a mysterious viral disease that affects mainly tilapia (NODA virus blind eye disease) [12]; 6: intensified cormorant predation $[13,14]$; 7 : natural cycled fluctuations in tilapia stock $[6,10]$.

The number of great cormorants (Phalcocorax carbo) wintering (from the end of October through March) in the Lake Kinneret region is approximated as 6000 (5000-7000). The predation rate of cormorants indicates a daily range of 300-1000 (most commonly 500) grams per bird. The cormorants are winter migratory birds, arriving towards the end of October and leaving in March (they stay for 100120 days). It has been documented that their diet comprises mostly of bleaks in October and November and of sub-commercial-sized $S$. galilaeus from January to March (100 days). Six thousand cormorants prey daily on $500 \mathrm{~g}$ of fish per bird during the 100 days from January to March, removing 300 tons of sub-commercial-sized S. galilaeus from the lake. It has to be considered that a fish the same size as one preyed on in January might have grown by $30-70 \%$ when fished in summer (legal size $>200 \mathrm{~g} / \mathrm{fish}$ ). Individually preyed tilapia of weight 50-70 g might grow up to a commercial size within 5-6 months. Consequently, the commercial value of such losses was approximated as US\$1.5-3.0 million. Such a damage to fishermen income and to the ecological
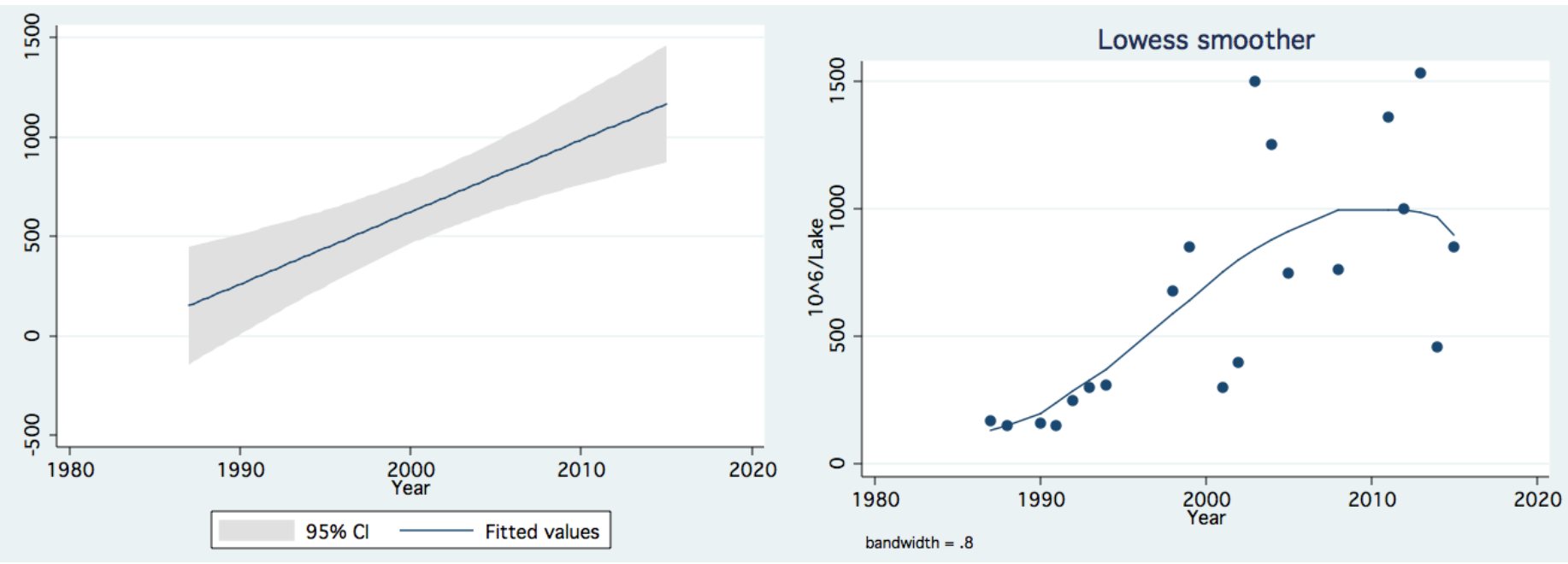

Figure 1: Temporal (1987-2015) changes of Fish Number (millions/lake)) As measured by acoustic surveys in Lake Kinneret, Left - Linear regression with confidence interval Right - LOWESS Smoother, band width -0.8 . 

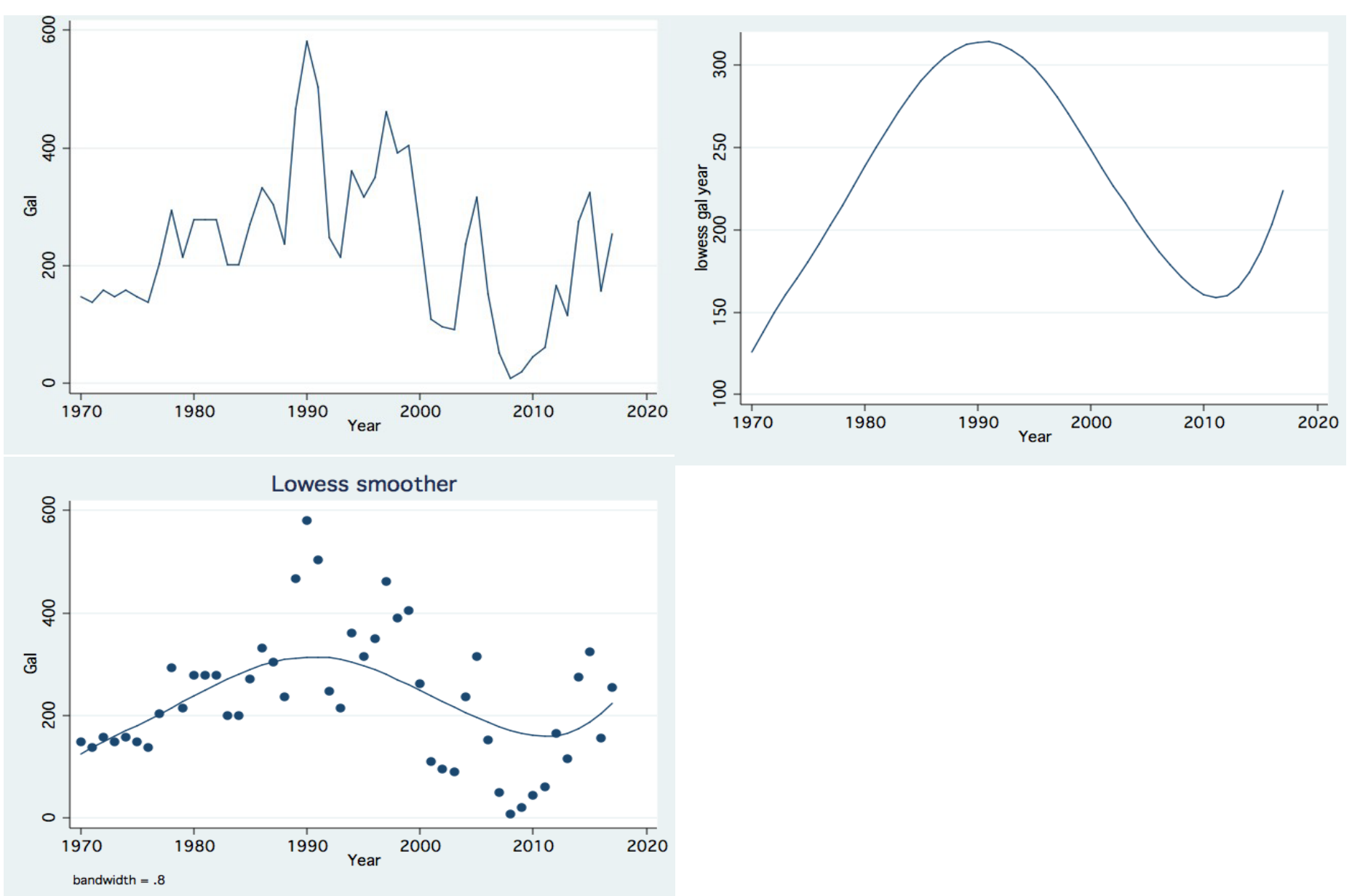

Figure 2: Temporal (1970-2017) changes of annual landings of Sarotherodon galilaeus: Left Upper: Line scatter; Right Upper: Trend of Changes by LOWESS (0.8); Left Lower: Lowess Smoother (Bandwidth 0.8);
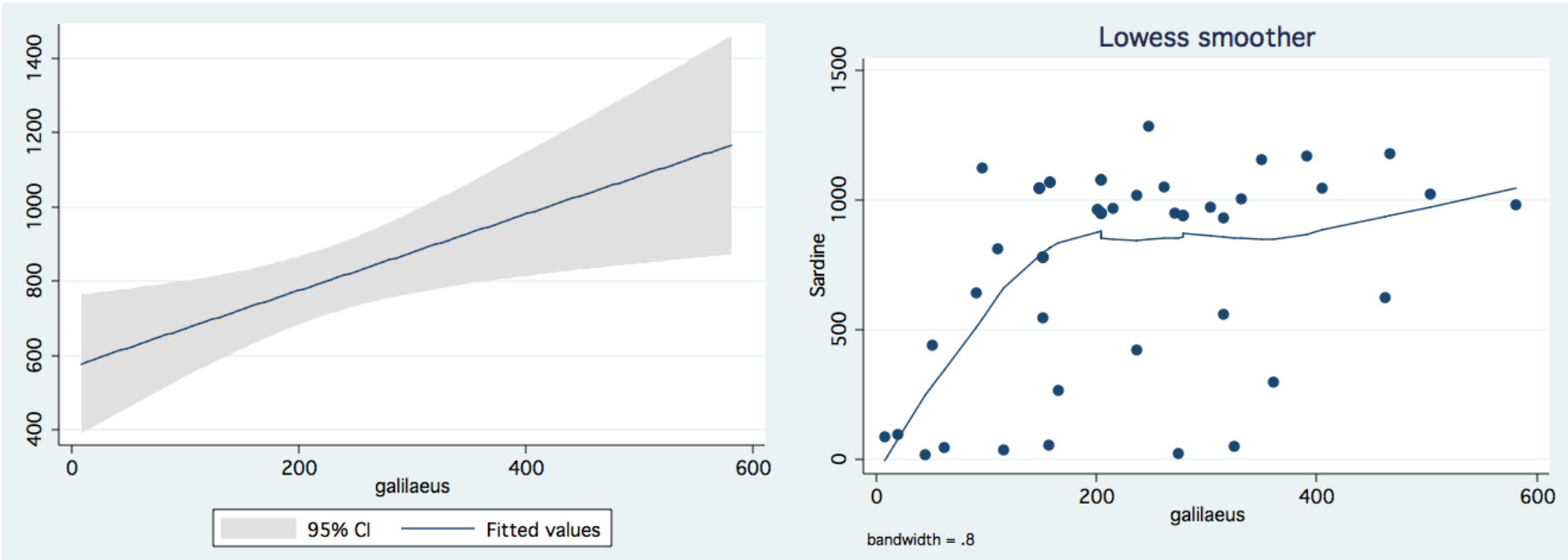

Figure 3: Annual Landing (tons) of Bleaks in relation to Sarotherodon galilaeus:Bleaks landing Vs S. galilaeus landings (1959-2016). Left - Linear Regression with Confidence interval (95\%). Right - LOWESS Smoother, band-width - 0.8 .

system can be reduced by aggressive deportation of the cormorants from Lake Kinneret and their night station site. The contribution of tilapia to the ecosystem, which is aimed at water quality protection, is the selective consumption of gradually reappearing Peridinium biomass [5,7].

\section{Conclusive Remarks}

The sharp decline in S. galilaeus landing in the 2000s is an extremity of the natural appearance of quasi-cyclic fluctuations in the S. galilaeus population size. High landing in the years 1970-2000 was 


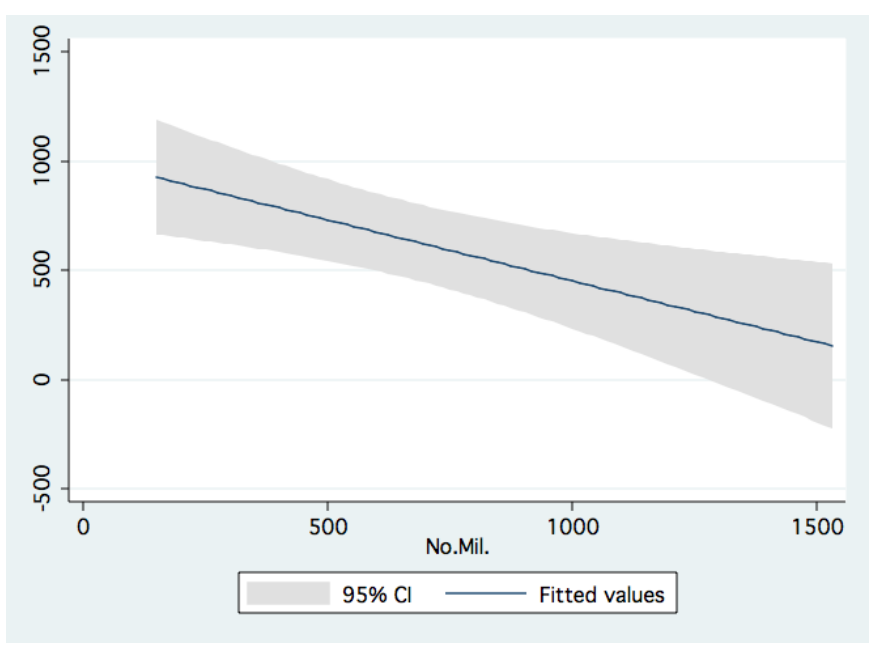

Figure 4: Linear Regression between Bleak annual landings (ton) and fish population size (acoustic documentation in millions) in Lake Kinneret (1987-2015).

correlated to heavy blooms of Peridinium which was dominated later by Cyanobacteria. Peridinium is a favored food by S. galilaeus, therefore the predation pressure of $S$. galilaeus on zooplankton was enhanced. The landing record confirms an increase in S. galilaeus accompanied by enhancement of bleak removal. The predictability of fishing ban indicates competition between proliferated bleaks and suppressed S. galilaeus. Such conditions are mostly predicted during drought seasons with nitrogen deficiency and Cyanobacteria takeover. Among parameters of climate change, temperature elevation is also included. Higher temperature enhances metabolic activity and increases food consumption. Therefore, fishing ban accompanied by bleak competition strength justifies objection of this recommendation. Lake Kinneret is not a completely open natural ecosystem. The hydrological management of Lake Kinneret is partly anthropogenic, i.e. humancontrolled. The anthropogenic involvement is mostly emphasized during drought conditions. As part of climate change, droughts are predicted to be enhanced. Human management is accompanied by fishery regulations. Nevertheless, fishery regulations are based on the natural trait and regulation of fishing efforts and introductions should not exceeding the natural structure. This kind of management policy has continued for many years. Of course, fishery rates fluctuate but within acceptable ranges or extremes. The crisis of S. galilaeus fishery presented in this paper has never been recorded before. The recommendation suggested here is the following: the long history of successful management policy implementations must go on. A change in long-term management methods is risky due to the natural reclamation capabilities of the ecosystem, accompanied by the validity of previous policies of which the principles are: introduction of a limited number of fingerlings of $S$. galilaeus, mugilids and silver carp; commercial and sport fishing maintenance under fishery regulations (technologies, net mesh-size); fishing ban enforcement in the breeding grounds (North-East part of the lake) during the spawning season of S. galilaeus; and tight inspection of the fish market (fish size and health). The rational behind fishery management is dual: lake water quality protection and sustenance of fishers' income. Total fishing ban for three years, which was wrongly suggested as part of reclamation, has the potential to damage both water quality and, obviously, fishers' source of income. The national constrained commitments do not leave a free space for ecological trials, and previous management designs are recommended. Conclusively, the cancelation of the fishing ban was justified. Forwarded recovery of S. galilaeus landings recoinciled the recommendation to reject the fishing-ban suggestion.

\section{Acknowledgement}

Warm thanks to J. Shapiro, M. Lev, Z. Snovsky, O. Sonin, Y. Fdida. A. Eldar and G. Rubinstein for their technical assistance and providing with Kinneret fishery information.

\section{References}

1. Ben-Tuvia A (1978) Chapter: Fishes, in: Lake Kinneret, Monographiae Biologicae 32 (C. Serruya ed.) Dr. Junk bv Publishers The Hague-Boston-London 1978, 407-430.

2. Gophen M (1992) Book: The Kinneret Book, Part a: The Lake, Ministry of DefenceIsrael. 160. (in Hebrew)

3. Gophen M (2018) Part C, in: Ecoloical Research in the Lake Kinneret and Hula Valley (Israel) Ecosystems, Scientific Research Publishing, Inc. USA, 187-281.

4. Gophen M (2019) The Replacement of Peridinium by Cyanobacteria in Lake Kinneret (Israel): A Commentary Review. Open Journal Modern Hydrlogy 9: 161-177.

5. Gophen M (2019) Book: Different Kinneret, Glilitooks Publisher, 160. (in Hebrew).

6. Pisanti S (2005) Quasi-cyclic fluctuations in St. Peter's Fish landings in Lake Kinneret-continues. Fisheries and Fish Breeding in Israel 1: 777-781.

7. Serruya CM, Gophen, U Pollingher (1980) Lake Kinneret: Carbon Flow Patterns and Ecosystem Management. Arch. Hydrobiol 88: 265-302.

8. Sarid S, J Shapiro (1959-2017) Fishery Department Agricultur Ministry-Lake Kinneret Branch 1970-2013. Fisheries in Israel: Chapters: Lake Kinneret.

9. Gophen M, Sonin O, M Lev, G Snovsky (2015) Regulated Fishery is Beneficial for The Sustainability of Fish Population in Lake Kinneret (Israel). Open Journal of Ecology 5: 513-527.

10. Pisanti SM, Ben-Yami, H Talpaz (1987) Quasi-Fluctuation in St. Peter`s Fish in Lake Kinneret and theie manage,ment implications,. A: The cyclic and the effect of effort. Fisheries and Fish Breeding in Israel 20: 26-38.

11. Walline P, KLL-Kinneret Limnlogical Laboratory-IOLR 1987-2005. Annual reports.

12. Eyngor MR, Zamostiano JE, Krmbou TA, Berkovitz H, Brcovier S Tinman, M. Lev, A. Hurvitz, M. Galeotti, E. Bachrach and and A. Eldar, 2014. Identification of Novel RNA Virus Lethal to Tilapia. Journal of Clinical Microbiology Volume 52 Number 12 December 2014, pp. 4137-4146.

13. Gophen M (2017) Tilapia Stock Suppression by the Great Cormorant (Falacrocorax carbo) in Lake Kinneret, Israel. Open Journal of Modern Hydrology 7: 153-164.

14. KLL-LKDB (Lake Kinneret Data Base), Kinneret Limnological Laboratory, IOLR Co, Ltd.1970-2013 Annual Reports.

\section{Citation:}

Gophen M (2021) Biennial (2007/8) Crisis of Sarotherodon galilaeus Fishery in Lake Kinneret (Israel): A Synopsis. Aquac Fish Stud Volume 3(2): 1-4. 